\title{
Knowledge, attitudes and self-reported practices of food service staff in nursing homes and long-term care facilities
}

\author{
Cecilia Buccheri ${ }^{\mathrm{a}}$, Caterina Mammina ${ }^{\mathrm{b}}$, Santo Giammanco ${ }^{\mathrm{a}}$, Marco Giammanco ${ }^{\mathrm{a}}$, Maurizio La Guardia ${ }^{\mathrm{a}}$, \\ Alessandra Casuccio ${ }^{\mathrm{c}, *}$ \\ a Division of Physiology and Human Nutrition, Department of Medicine, Pneumology, Physiology and Human Nutrition, Palermo University, Via A. Elia, 90127 Palermo, Italy \\ ${ }^{\mathrm{b}}$ Department of Sciences for Health Promotion "G.D'Alessandro", Palermo University, Via del Vespro 133, 90127 Palermo, Italy \\ c Department of Clinical Neuroscience, Palermo University, Italy, Via L. Giuffrè 13, 90127 Palermo, Italy
}

\section{A R T I C L E I N F O}

\section{Article history:}

Received 27 July 2009

Received in revised form 7 April 2010

Accepted 17 April 2010

\section{Keywords:}

Food safety

Long-term care facility

Nursing home

Elderly

Knowledge

Attitudes and practices

\begin{abstract}
A B S T R A C T
The aim of this study was to investigate knowledge, attitudes and practices of food service staff in nursing homes and long-term care facilities for the elderly in Sicily, Italy. Association with some demographic and work-related variables was also investigated. This survey provides information and outlines many complex questions concerning the basics of food hygiene. Education level, length of service in the employment and attending courses on food hygiene influenced the knowledge, attitudes and practices of food service staff. This study has evidenced the need for continuous training among food service staff regarding food safety in LTCF and nursing homes.
\end{abstract}

(c) 2010 Elsevier Ltd. All rights reserved.

\section{Background}

Elderly persons represent an increasing proportion of the population in Europe and worldwide. In 2004 elderly people accounted for 75.3 million, i.e. $16.4 \%$ of the whole European population. By 2050 it is estimated that 134.5 million Europeans will be more than 65 year-old aged and older adults will increase up to $29.9 \%$ of the population (McGrath, 2003). The larger increase will be in Spain (35.6\%), in Italy (35.5\%) and in Greece (32.5\%). The growing segment of persons older than 65 years forms a special population at risk for infections (Gerba, Rose, \& Haas, 1996; Greig \& Lee, 2009; Kendall, Hillers, \& Medeiros, 2006). Particularly, more than 80 year-old subjects are at increased risk for both infections and death from infections, including foodborne illnesses, because of the decrease in immune function, comorbidities and other factors, such as malnutrition and inactivity (Strausbaugh, 2001). Malnutrition and the consequent impairment of cell-mediated immunity are very common in nursing home residents and may be more diffuse within the elderly living in community than is generally thought (Alvarez, Monereo, Ortiz, \& Salido, 2004; Greig \& Lee,

\footnotetext{
* Corresponding author. Address: Dipartimento di Neuroscienze Cliniche Università di Palermo, Via Liborio Giuffrè 13, 90127 Palermo, Italy. Tel.: +39 91 6553929; fax: +39916553030.

E-mail address: casuccio@unipa.it (A. Casuccio).
}

2009; Levine, Smart, Archer, Bean, \& Tauxe, 1991; Smith, 1998). Moreover, geriatric patients may be the preferential victims of new or emerging infections in hospitals and other health-care settings (Zimmerman, Gruber-Baldini, Hebel, Sloane, \& Magaziner, 2002).

Long-term care facilities (LTCF) deliver various services to persons with a range of functional disability and disease. While some of these facilities offer care to younger persons also and deliver psychiatric as well as medical care, most of them are nursing homes for the elderly. Infections are common in LTCF and nursing home residents, the most frequent endemic infections involving respiratory, urinary and enteric tracts, skin and soft tissue. Gastrointestinal outbreaks, including those caused by bacteria such as Escherichia coli 0157:H7 and Salmonella, as well as Norovirus, are common also (Nicolle, 2001). Moreover, LTCF residents have multiple chronic comorbidities that complicate recognition of infection. Elderly persons, compared with younger adults, have higher incidence of infections caused by Listeria, Salmonella, Vibrio, Yersinia and E. coli 0157, Clostridium perfringens and Campylobacter jejuni, due to the decrease in mobility and gastric acid production (Greig \& Lee, 2009).

Nursing homes are residential facilities for persons who require nursing care and related medical or psychosocial services. Most of nursing home residents fall into the geriatric age range and exhibit virtually all the risk factors (ageing-associated physiologic and 
pathologic changes, functional disability, institutionalization and invasive devices) associated with the high occurrence of infection (Layton, Calliste, Gomez, Patton, \& Brooks, 1997). The common occurrence and dire consequences of infectious disease outbreaks in nursing homes often go unrecognized and unappreciated. Moreover, the cyclic circuit of visitors, ancillary staff, food service and the residents themselves back and forth between the health-care setting and the community is susceptible to vehicle bidirectionally pathogens and drug resistant bacteria (Cecchetto, Zanardo, \& Tossani, 2006; Nicolle, 2001; Nicolle, Strausbaugh, \& Garibaldi, 1996). Emerging pathogens account for some of the outbreaks in nursing homes (Layton et al., 1997).

Health-care workers can play an important role in preventing and control foodborne illness by educating patients about the risks of foodborne diseases, reporting cases to Public Health authorities and making food safety recommendations (Exner, Peters, Engelhart, Mielke, \& Nassauer, 2004; Geng \& Thieves, 2002; Martin et al., 2001; Parks, Haines, Foreman, McKinstry, \& Maxwel, 2005; Salva et al., 2009).

The aim of this study was to investigate knowledge, attitudes and practices of the ancillary staff including nurses and food service workers who were being routinely involved in food service functions in nursing homes and LTCF for the elderly and chronic patients of the Health Districts in the province of Palermo, Italy.

\section{Methods}

\subsection{Setting}

For the purpose of the study, we selected all the 10 nursing homes for the elderly belonging to the Health Districts of the province of Palermo and the only long-term care facility in the area surveyed with specialized inpatient services for individuals with mental illnesses.

Nursing homes for the elderly are in both the urban and extraurban areas of the Palermo province. The food catering service is being provided by in-house premises, where HACCP systems and quality assurance programs are running in accordance with the UNI EN ISO 9002 standards. The meals are plated individually according to patients choice or dietary regimen. The self-sufficient individuals have meals together in dining rooms, whereas those not self-sufficient have meals in bed.

In the LTCF under study the food service is contracted out to an external caterer who employs a traditional cook and serve production scheme and a plated meal distribution system. In this premise HACCP-based risk management procedures are in place according to the existing legislation. The meals are prepared according to patients choice or dietary regimen and delivered for immediate serving.

\subsection{Survey instrument}

From January to June 2008, knowledge, attitudes and practices about food safety and hygiene of the nursing and ancillary staff working in nursing homes for the elderly and in LTCF, were investigated. The survey was conducted by means of a self-administered, semi-structured questionnaire prepared based upon questionnaires previously used and validated in studies done in Italy and in other countries (Angelillo, Foresta, Scozzafava, \& Pavia, 2001; Angelillo, Viggiani, Greco, \& Rito, 2001; Angelillo, Viggiani, Rizzo, \& Bianco, 2000; Askarian, Kabir, Aminbaig, Memish, \& Jafari, 2004; Buccheri et al., 2007). Because the survey data did not influence patient management and the issue being investigated is a matter of public record, ethical approval for the study was not required. A written consent of participants was elicited and confiden- tiality was warranted. After obtaining approval, the questionnaire was addressed to all nurses and ancillary staff potentially involved in food related functions, and, to minimize the non-respondent prevalence, the questionnaire was self-administered and confidentiality of the answers was warranted. If no answer had been received within 2 weeks of sending the questionnaire, a new one was sent to urge the recipients to complete it.

The questionnaire included five sections: (a) demographic characteristics, employment status and hospital/ward where the nurse and/or ancillary staff worked; (b) knowledge about food hygiene; (c) attitudes towards prevention of foodborne diseases; (d) measures to be used in prevention of foodborne diseases; (e) sources of information about food hygiene. The questions concerning knowledge about foodborne disease agents and foods epidemiologically linked to transmission of pathogens listed some microrganisms and asked to choose from among three options - yes, no, do not know - about their association with foodborne disease and to couple at least one food vehicle to each pathogen. Because of the peculiar characteristics of the population under investigation, hepatitis B virus (HBV) was introduced within the potential foodborne agents. Answers were classified as correct when contained exclusively food items with a well recognized role as a vehicle for the pathogen under analysis. The answers in the section of practices were simplified, including only three options (always, often, never).

\subsection{Statistical procedures}

Statistical analysis of association between questionnaire answers and demographic characteristics of respondents was performed by categorization of answers for each section as dichotomous variables: knowledge was categorized and recorded as correct vs. incorrect/unknown, attitudes as agreement vs. disagreement/uncertain and practices as safe, when answer was always (never for the question D6), vs. unsafe, when answer was often or never (always for the question D6).

Frequency analysis results of food safety knowledge, attitude and practice for the respondents were performed by Pearson's chi-square test and reported only for the items where the proportion of correct answers was $95 \%$ or less. The one-way analysis of variance (ANOVA) was used to evaluate difference in parametric variables.

Data were analyzed by the Epi Info software (version 6.0, CDC, Atlanta, GA, US) and the SPSS Software 14.0 version (SPSS, Inc., Chicago, Ill, US). Cross-tabulation and chi-square tests were carried out to determine the relationship between nurses' knowledge, attitudes and practices and demographic data. Moreover, to explore whether this relationship systematically varied by specific sociodemographic characteristics, a series of logistic regression analyses yielding hazard ratios $(95 \% \mathrm{CI})$ and $P$ values were performed. Independent variables included age, gender, education, length of service in the employment/ward and having attended courses on food hygiene. In all analyses, differences were considered statistically significant at $P \leqslant 0.05$.

\section{Results}

A total of 502 subjects returned the compiled the questionnaire, 241 out of 278 (86.7\%) ancillary staff members and 102 out of 115 nurses (88.7\%) in the LTCF, and all the 159 components of the food service staff in the nursing homes (Table 1 ).

The respondents did not significantly differ based upon their working site by demographics and length of service in the employment (Table 1). The majority of the respondents were females (66.9\%), with a mean age of 40 years and a most prevalent educa- 
Table 1

Demographic characteristic of services staff.

\begin{tabular}{|c|c|c|c|}
\hline Characteristics of survey respondents & $\begin{array}{l}\text { Long-term } \\
\text { care facility }\end{array}$ & $\begin{array}{l}\text { Nursing } \\
\text { homes }\end{array}$ & $P$ \\
\hline Gender No. (\%) & $(343)^{a}$ & $(159)^{\mathrm{a}}$ & \\
\hline Male & $118(34.4)$ & $48(30.2)$ & 0.35 \\
\hline Female & $225(65.6)$ & $111(69.8)$ & \\
\hline Age (yr) & $(343)^{\mathrm{a}}$ & $(159)^{\mathrm{a}}$ & 0.42 \\
\hline Mean $( \pm S D)$ & $39.6(7.4)$ & $40.2(8.3)$ & \\
\hline \multirow{2}{*}{$\begin{array}{l}\text { Length of service in the employment (yr), } \\
\text { mean }( \pm S D)\end{array}$} & $(343)^{a}$ & $(159)^{a}$ & \\
\hline & $12.8(6.9)$ & $13.4(10.1)$ & 0.48 \\
\hline \multirow{2}{*}{$\begin{array}{l}\text { Length of service in the present ward } \\
\quad(\mathrm{yr}) \text {, mean }( \pm S D)\end{array}$} & $(343)^{a}$ & $(159)^{\mathrm{a}}$ & \\
\hline & $12.1(6.9)$ & $12.2(9.4)$ & 0.95 \\
\hline Education level yrs, No. (\%) & $(282)^{\mathrm{a}}$ & $(129)^{a}$ & \\
\hline 8 & $18(6.4)$ & $10(7.8)$ & \\
\hline 13 & $194(68.8)$ & $92(71.3)$ & 0.64 \\
\hline$\geqslant 16$ & $70(24.8)$ & 27 (20.9) & \\
\hline $\begin{array}{l}\text { Attending at least one course on food } \\
\text { hygiene and foodborne diseases, No. } \\
(\%)\end{array}$ & $(305)^{\mathrm{a}}$ & $(141)^{\mathrm{a}}$ & \\
\hline No & $56(18.4)$ & $32(22.7)$ & \\
\hline Yes & $249(81.6)$ & $109(77.3)$ & 0.28 \\
\hline
\end{tabular}

a The number of participants responding to the questions is indicated in parentheses.

tional level of high school diploma (13 years). Most respondents (80.3\%) had attended at least one training course on food hygiene and foodborne diseases prevention.

Only the answers where agreement within respondents was $95 \%$ or lower were reported and further analyzed.

\subsection{Knowledge}

The most significant responses for this area are described in Table 2. The majority (75.7\%) of the respondents agreed that preparing food in advance may contribute to risk of food poisoning, and almost all (91.6\%) proved be aware of the risks related to reheating dishes prior to consumption. Although $80.3 \%$ of respondents believed that wearing gloves, while handling food, reduce risk of foodborne disease to consumers, $71.7 \%$ of them showed awareness of protective effects of this procedure for the food workers and $22.7 \%$ denied these effects. Furthermore, $18.9 \%$ of the interviewed subjects did not correctly answer or did not answer at all to the question about the correct working temperature of a refrigerator. Moreover, $82 \%$ and $24.2 \%$ of the respondents, respectively, did not correctly identified the proper storage temperature of hot and cold ready to eat foods. Questions about food items associated to the transmission of hepatitis A, hepatitis B, salmonellosis, cholera, botulism and gastroenteritis were most frequently answered by checking an incorrect option or unanswered (Table 2 ).

\subsection{Attitudes}

The most significant responses for this area are illustrated in Table 3. The majority (83.9\%) of the respondents stated that they intended to separate cooked from raw foods, but $16.1 \%$ denied the need of adopting this key measure to prevent cross-contamination or unanswered. Only a low proportion of respondents (15.1\%) was unaware that defrosted food should not be refrozen. More than $90 \%$ of the respondents agreed that use of protective clothing and gloves, knowledge and monitoring of refrigerator and freezer temperatures and proper storage of foodstuffs play an important role in preventing food spoilage and health hazards to consumers. The statement that personnel with abrasions or cuts on fingers or
Table 2

Respondent's food safety knowledge.

\begin{tabular}{|c|c|c|c|}
\hline \multirow[t]{2}{*}{ Statement } & \multicolumn{3}{|c|}{ Responses $n(\%)$} \\
\hline & Correct & $\begin{array}{l}\text { Not } \\
\text { correct }\end{array}$ & $\begin{array}{l}\text { Do not } \\
\text { know }\end{array}$ \\
\hline $\begin{array}{l}\text { B1. Preparation of food in advance is likely to } \\
\text { contribute to food poisoning }(489)^{\mathrm{a}}\end{array}$ & $\begin{array}{l}370 \\
(75.7)\end{array}$ & $\begin{array}{l}84 \\
(17.2)\end{array}$ & $\begin{array}{l}35 \\
(7.1)\end{array}$ \\
\hline $\begin{array}{l}\text { B2. Reheating of food is likely to contribute to } \\
\text { food contamination }(497)^{\mathrm{a}}\end{array}$ & $\begin{array}{l}455 \\
(91.6)\end{array}$ & $\begin{array}{l}27 \\
(5.4)\end{array}$ & $\begin{array}{l}15 \\
(3.0)\end{array}$ \\
\hline $\begin{array}{l}\text { B5. Wearing gloves while handling food } \\
\text { minimizes risk of transmitting infection to } \\
\text { consumers }(496)^{\mathrm{a}}\end{array}$ & $\begin{array}{l}398 \\
(80.3)\end{array}$ & $\begin{array}{l}83 \\
(16.7)\end{array}$ & $\begin{array}{l}15 \\
(3.0)\end{array}$ \\
\hline $\begin{array}{l}\text { B6. Wearing gloves while handling food } \\
\text { minimizes risk of transmitting infection to } \\
\text { food service staff }(481)^{a}\end{array}$ & $\begin{array}{l}345 \\
(71.7)\end{array}$ & $\begin{array}{l}109 \\
(22.7)\end{array}$ & $\begin{array}{l}27 \\
(5.6)\end{array}$ \\
\hline $\begin{array}{l}\text { B7. The correct temperature for a refrigerator } \\
\text { is: }<1{ }^{\circ} \mathrm{C}, 1-5^{\circ} \mathrm{C}, 6-10^{\circ} \mathrm{C}, 11-15^{\circ} \mathrm{C}, 16-20^{\circ} \mathrm{C} \\
(477)^{\mathrm{a}}\end{array}$ & $\begin{array}{l}387 \\
(81.1)\end{array}$ & $\begin{array}{l}90 \\
(18.9)\end{array}$ & 0 \\
\hline $\begin{array}{l}\text { B8. Hot ready to eat foods should be } \\
\text { maintained at: } 21-30^{\circ} \mathrm{C}, 31-40^{\circ} \mathrm{C}, 41- \\
50^{\circ} \mathrm{C}, 51-60^{\circ} \mathrm{C}, 61-70^{\circ} \mathrm{C}(433)^{\mathrm{a}}\end{array}$ & $\begin{array}{l}78 \\
(18.0)\end{array}$ & $\begin{array}{l}355 \\
(82.0)\end{array}$ & 0 \\
\hline $\begin{array}{l}\text { B9. Cold ready to eat foods should be } \\
\text { maintained at: }<1^{\circ} \mathrm{C}, 1-4^{\circ} \mathrm{C}, 5-8^{\circ} \mathrm{C}, 9- \\
12^{\circ} \mathrm{C}, 13-16^{\circ} \mathrm{C}(459)^{\mathrm{a}}\end{array}$ & $\begin{array}{l}348 \\
(75.8)\end{array}$ & $\begin{array}{l}111 \\
(24.2)\end{array}$ & 0 \\
\hline $\begin{array}{l}\text { B10b. Hepatitis B can be transmitted by food } \\
(366)^{\mathrm{a}}\end{array}$ & $\begin{array}{l}273 \\
(74.6)\end{array}$ & $\begin{array}{l}70 \\
(19.1)\end{array}$ & $\begin{array}{l}23 \\
(6.3)\end{array}$ \\
\hline $\begin{array}{l}\text { B10d. Cholera can be transmitted by food } \\
(439)^{\mathrm{a}}\end{array}$ & $\begin{array}{l}352 \\
(80.2)\end{array}$ & $\begin{array}{l}58 \\
(13.2)\end{array}$ & $\begin{array}{l}29 \\
(6.6)\end{array}$ \\
\hline $\begin{array}{l}\text { B11a. Food items associated to the } \\
\text { transmission of Hepatitis A }(398)^{\mathrm{a}}\end{array}$ & $\begin{array}{l}241 \\
(60.6)\end{array}$ & $\begin{array}{l}157 \\
(39.4)\end{array}$ & 0 \\
\hline $\begin{array}{l}\text { B11b. Food items associated to the } \\
\text { transmission of Hepatitis B }(159)^{\mathrm{a}}\end{array}$ & $\begin{array}{l}102 \\
(64.2)\end{array}$ & $\begin{array}{l}57 \\
(35.8)\end{array}$ & 0 \\
\hline $\begin{array}{l}\text { B11c. Food items associated to the transmission } \\
\text { of Salmonellosis }(421)^{\mathrm{a}}\end{array}$ & $\begin{array}{l}338 \\
(80.3)\end{array}$ & $\begin{array}{l}83 \\
(19.7)\end{array}$ & 0 \\
\hline $\begin{array}{l}\text { B11d. Food items associated to the } \\
\text { transmission of Vibrio cholerae }(346)^{\mathrm{a}}\end{array}$ & $\begin{array}{l}307 \\
(88.7)\end{array}$ & $\begin{array}{l}39 \\
(11.3)\end{array}$ & 0 \\
\hline $\begin{array}{l}\text { B11e. Food items associated to the } \\
\text { transmission of Botulism }(407)^{\mathrm{a}}\end{array}$ & $\begin{array}{l}319 \\
(78.4)\end{array}$ & $\begin{array}{l}88 \\
(21.6)\end{array}$ & 0 \\
\hline $\begin{array}{l}\text { B11f. Food items associated to the transmission } \\
\text { of Gastroenteritis }(378)^{\mathrm{a}}\end{array}$ & $\begin{array}{l}139 \\
(36.8)\end{array}$ & $\begin{array}{l}239 \\
(63.2)\end{array}$ & 0 \\
\hline
\end{tabular}

a The number of participants responding to the questions is indicated in parentheses.

Table 3

Respondent's food safety attitudes.

\begin{tabular}{llll}
\hline \multirow{2}{*}{ Statement } & \multicolumn{3}{l}{ Responses $n(\%)$} \\
\cline { 2 - 4 } & Yes & No & Uncertain \\
\hline C1. Raw foods should be kept separated from & 416 & 57 & $23(4.6)$ \\
$\quad$ cooked foods (496) & $(83.9)$ & $(11.5)$ & \\
C2. Defrosted food should not be refrozen & 75 & 415 & $6(1.2)$ \\
$\quad(496)^{a}$ & $(15.1)$ & $(83.7)$ & \\
C7. Food service staff with abrasions or cuts on & 454 & 36 & $7(1.4)$ \\
hands should not touch unwrapped food & $(91.3)$ & $(7.3)$ & \\
$(497)^{\text {a }}$ & & & \\
\hline
\end{tabular}

a The number of participants responding to the questions is indicated in parentheses.

hands should not handle unwrapped food was approved by $91.3 \%$ of the respondents.

\subsection{Practices}

Responses for this section are displayed in Table 4. An unexpected, but percentually limited, mixed set of responses was evident when considering the practice of washing hands before and after handling unwrapped foods. Up to $83.8 \%$ of respondents for raw foods and $80.9 \%$ for cooked foods stated that they always washed their hands before or after touching food. Only a little number of respondents stated that they washed hands occasionally only, while touching unwrapped foods. The majority (65.9\%) 
Table 4

Respondent's food safety practices.

\begin{tabular}{|c|c|c|c|}
\hline \multirow[t]{2}{*}{ Statement } & \multicolumn{3}{|c|}{ Responses $n(\%)$} \\
\hline & Always & Often & Never \\
\hline $\begin{array}{l}\text { D1. Do you wash your hands before touching } \\
\text { unwrapped raw food? }(500)^{\mathrm{a}}\end{array}$ & $\begin{array}{l}413 \\
(82.6)\end{array}$ & $\begin{array}{l}83 \\
(16.6)\end{array}$ & $\begin{array}{l}4 \\
(0.8)\end{array}$ \\
\hline $\begin{array}{l}\text { D2. Do you wash your hands after touching } \\
\text { unwrapped raw food? }(499)^{\mathrm{a}}\end{array}$ & $\begin{array}{l}418 \\
(83.8)\end{array}$ & $\begin{array}{l}78 \\
(15.6)\end{array}$ & $\begin{array}{l}3 \\
(0.6)\end{array}$ \\
\hline $\begin{array}{l}\text { D3. Do you wash your hands before touching } \\
\text { unwrapped cooked food? (493) }\end{array}$ & $\begin{array}{l}399 \\
(80.9)\end{array}$ & $\begin{array}{l}91 \\
(18.5)\end{array}$ & $\begin{array}{l}3 \\
(0.6)\end{array}$ \\
\hline $\begin{array}{l}\text { D4. Do you wash your hands after touching } \\
\text { unwrapped cooked food? }(489)^{\mathrm{a}}\end{array}$ & $\begin{array}{l}351 \\
(71.8)\end{array}$ & $\begin{array}{l}132 \\
(27.0)\end{array}$ & $\begin{array}{l}6 \\
(1.2)\end{array}$ \\
\hline $\begin{array}{l}\text { D5. Do you use separate kitchen utensils to } \\
\text { prepare cooked and raw food? }(492)^{\mathrm{a}}\end{array}$ & $\begin{array}{l}324 \\
(65.9)\end{array}$ & $\begin{array}{l}136 \\
(27.6)\end{array}$ & $\begin{array}{l}32 \\
(6.5)\end{array}$ \\
\hline $\begin{array}{l}\text { D6. Do you thaw frozen food at room } \\
\text { temperature? }(498)^{\mathrm{a}}\end{array}$ & $\begin{array}{l}275 \\
(55.2)\end{array}$ & $\begin{array}{l}180 \\
(36.2)\end{array}$ & $\begin{array}{l}43 \\
(8.6)\end{array}$ \\
\hline D7. Do you check shelf life of the products? $(492)^{a}$ & $\begin{array}{l}451 \\
(91.7)\end{array}$ & $\begin{array}{l}36 \\
(7.3)\end{array}$ & $\begin{array}{l}5 \\
(1.0)\end{array}$ \\
\hline D8. Do you inspect integrity of packages? $(493)^{a}$ & $\begin{array}{l}441 \\
(89.5)\end{array}$ & $\begin{array}{l}46 \\
(9.3)\end{array}$ & $\begin{array}{l}6 \\
(1.2)\end{array}$ \\
\hline
\end{tabular}

a The number of participants responding to the questions is indicated in parentheses.

of the respondents always used separate utensils for cooked and raw foods, $27.6 \%$ only falling in the category "often". Thawing frozen food at room temperature proved to be an extensively used practice: indeed, only $43(8.6 \%)$ of the 502 interviewed workers stated that they never were applying such a procedure. On the contrary, checking shelf life of the products and integrity of packages proved to be a very diffuse behaviour: $91.7 \%$ and $89.5 \%$ of the respondents always observed these procedure, respectively, while buying foodstuffs.

\subsection{Relationship between response's pattern and socio-demographic characteristics}

Age, length of service, education and attending training courses on food safety were significantly associated by logistic regression analysis to the knowledge, attitude and behaviour patterns of response (Table 5 ).

More in detail, a lower age class was significantly associated to some unsafe answer patterns in the sections of knowledge and attitudes, namely about the proper temperatures the hot ready to eat food should maintain and possible refreezing of defrosted foods. A shorter length of service was associated with unsafe behaviours, in particular those concerning hand hygiene, and to the awareness of the opportunity for protecting themselves from the potential acquisition of foodborne pathogens, while handling foods, by wearing gloves. The transmission routes of hepatitis B were better known by the subjects with a less than 10 year-long length of service. Education level was significantly associated to a better performance of the respondents in the section knowledge, but this was not true for the attitude and behaviour sections answer pattern. Of interest, the education level category was inversely associated to the proportion of respondents who agreed about the need for separate raw from cooked foods.

Attending courses on food safety and foodborne disease prevention was consistently associated to a correct answering patterns to some key questions in knowledge section, particularly those concerning reheating foods, temperature of storage, transmission of hepatitis B and cholera.

Particularly, there was a strong positive relation between the knowledge about the habit of wearing gloves while handling food to minimize risk of transmitting infection to consumers or food service staff and the practice to wash the hands after touching unwrapped cooked food.

\section{Discussion}

This survey provides information and outlines many complex questions concerning the knowledge, attitudes and practices of the staff working in LTCF and nursing homes for the elderly in Palermo, Italy.

Among the respondents, there was a generalized lack of knowledge of the safe temperatures of food maintenance and the transmission routes of some major foodborne diseases. The finding that proportions as high as $82.0 \%$ and $24.2 \%$, respectively, did not know the critical temperature of storage of hot and cold ready to eat foods is of special concern, since food workers in the nursing homes and LTCF under study are routinely involved in the receipt of meals from the external caterer or, in any case, in the supervision of their delivery to patients. Knowledge about the correct temperatures was significantly more frequent in personnel with a higher school education level and having attended training courses on food hygiene. A similar lack of knowledge about critical temperatures of hot and cold ready to eat foods have been previously reported among food service staff in hospitals in Italy (Buccheri et al., 2007), Iran (Askarian et al., 2004) and in Turkey (Tokuç, Ekuklu, Berberoğlu, Bilge, \& Dedeler, 2009). Foods are often contaminated with pathogens and cross-contamination and/or inadequate temperature controls are frequent contributing factors to foodborne diseases. Moreover, the importance of maintaining foods at safe temperatures has been widely documented and is a basic issue in the implementation of the HACCP system (Decreto Legislativo No. 155 del 26.5.1997; Regulation (EC) No. 852/2004 of the European Parliament and of the Council on the hygiene of foodstuffs).

This survey also revealed a general positive attitude toward safe storage practices involving temperature control and correct handling of food using adequate clothing and gloves, but respondents fared worse when they were asked about cross-contamination and refreezing. However, preventing cross-contamination has a crucial role in food safety risk management. Similar results have been obtained from previous studies in hospitals (Angelillo, Foresta, et al., 2001; Angelillo, Viggiani, et al., 2001; Askarian et al., 2004; Buccheri et al., 2007) and in LTCFs (Nelson et al., 2008).

Self-reported behaviours revealed improper practices, such as sharing of utensils for raw and cooked foods and thawing of frozen food at room temperature. Moreover, washing hands before and after touching unwrapped and raw food was not so generalized as expected in a personnel who should have been constantly trained about hand hygiene. Hand hygiene, however, is considered more critical in the pathogens control than cleaning and disinfection of environmental surfaces (Dettenkofer \& Spencer, 2007).

The results of regression logistic analysis showed significant differences in respondent's knowledge, attitudes and practices as influenced by age, length of service in the employment, education and attending training courses on food hygiene. It could be interesting to outline that training in food safety was the only variable able to consistently guide the respondents towards safer answering options. On the contrary, education and length of service proved to be associated to some unexpected and apparently incongruent findings, in particular about some critical issues such as separating raw from cooked foods. Overall, studies on food safety are inconsistent with regard to the relationship between risk perception and age (Klontz, Timbo, Fein, \& Levy, 1995). Moreover, our findings are consistent with those of other studies, in which lower education levels were reported to be associated with safer food handling behaviours (Altekruse, Yang, Timbo, \& Angulo, 1999; Medeiros, Hillers, Kendall, \& Mason, 2001; Patil, Cates, \& Morales, 2005).

This study had some limitations. The overall response rate for few questions, particularly regarding the knowledge, was rather 
Table 5

Selected knowledge, attitudes and practices as influenced by some demographic characteristics of respondents (regression logistic analysis and HRs), No. (\%).

\begin{tabular}{|c|c|c|c|c|}
\hline Variable & Correct No. (\%) & Not correct/do not know No. (\%) & $P$ & $\operatorname{HR}(95 \% \mathrm{CI})$ \\
\hline \multicolumn{5}{|c|}{ B1. Preparation of food in advance is likely to contribute to food poisoning } \\
\hline Yes & $88(86.3)$ & $14(13.7)$ & \multirow[t]{2}{*}{0.003} & \multirow[t]{2}{*}{$0.40(0.21-0.73)$} \\
\hline No & $239(71.6)$ & $95(28.4)$ & & \\
\hline \multicolumn{5}{|c|}{ B2. Reheating of food is likely to contribute to food contamination } \\
\hline \multicolumn{5}{|c|}{ Attending courses } \\
\hline Yes & $101(97.1)$ & $3(2.9)$ & \multirow[t]{2}{*}{0.026} & \multirow[t]{2}{*}{$0.25(0.08-0.85)$} \\
\hline No & $302(89.6)$ & $35(10.4)$ & & \\
\hline \multicolumn{5}{|c|}{ B5. Wearing gloves while handling food minimizes risk of transmitting infection to consumers } \\
\hline \multicolumn{5}{|c|}{ Education level } \\
\hline 8 & $88(67.7)$ & $42(32.3)$ & \multirow[t]{3}{*}{0.007} & \multirow[t]{3}{*}{$2.86(1.33-6.14)$} \\
\hline 13 & $192(84.6)$ & $35(15.4)$ & & \\
\hline 16 & $60(85.7)$ & $10(14.3)$ & & \\
\hline \multicolumn{5}{|c|}{ B6. Wearing gloves while handling food minimizes risk of transmitting infection to food service staff } \\
\hline Education 1 & & & & \\
\hline 8 & $70(56.0)$ & $55(44.0)$ & 0.004 & $2.65(1.37-5.13)$ \\
\hline 13 & $167(75.9)$ & $53(24.1)$ & & \\
\hline 16 & $54(77.1)$ & $16(22.9)$ & & \\
\hline Length of $s$ & & & & \\
\hline$\leqslant 10$ & $102(63.0)$ & $60(37.0)$ & 0.026 & $2.29(1.10-4.79)$ \\
\hline $11-20$ & $145(75.9)$ & $46(24.1)$ & & \\
\hline$>20$ & $43(79.6)$ & $11(20.4)$ & & \\
\hline B7. The cor & is: $<1^{\circ} \mathrm{C}, 1-5^{\circ} \mathrm{C}$ & $15^{\circ} \mathrm{C}, 16-20^{\circ} \mathrm{C}$ & & \\
\hline Education 1 & & & & \\
\hline 8 & 89 (72.9) & $33(27.1)$ & 0.012 & $2.92(1.26-6.74)$ \\
\hline 13 & $176(80.7)$ & $42(19.3)$ & & \\
\hline 16 & $63(88.7)$ & $8(11.3)$ & & \\
\hline B8. Hot rea & ned at: $21-30^{\circ} \mathrm{C}$, & $-50^{\circ} \mathrm{C}, 51-60{ }^{\circ} \mathrm{C}, 61-70^{\circ} \mathrm{C}$ & & \\
\hline Attending $\mathrm{c}$ & & & & \\
\hline Yes & $40(43.0)$ & $53(57.0)$ & $<0.0005$ & $0.14(0.09-0.26)$ \\
\hline No & $30(10.1)$ & $266(89.9)$ & & \\
\hline Age & & & & \\
\hline$<35$ & $14(14.4)$ & $83(85.6)$ & 0.003 & $3.47(1.52-7.92)$ \\
\hline $35-50$ & $33(14.0)$ & $203(86.0)$ & $<0.0005$ & $3.60(1.68-7.28)$ \\
\hline$>50$ & $17(37.0)$ & $29(63.0)$ & & \\
\hline B9. Cold re & ined at: $<1^{\circ} \mathrm{C}, 1-$ & $9-12{ }^{\circ} \mathrm{C}, 13-16{ }^{\circ} \mathrm{C}$ & & \\
\hline Education 1 & & & & \\
\hline 8 & $84(69.4)$ & $37(30.6)$ & 0.025 & $2.36(1.11-5.0)$ \\
\hline 13 & $155(74.9)$ & $52(25.1)$ & & \\
\hline 16 & $59(84.3)$ & $11(15.7)$ & & \\
\hline B10b. Hepa & & & & \\
\hline Length of $s$ & & & & \\
\hline$\leqslant 10$ & $102(80.3)$ & 25 (19.7) & 0.046 & $0.42(0.18-0.98)$ \\
\hline $11-20$ & $104(73.8)$ & $37(26.2)$ & & \\
\hline$>20$ & $21(63.6)$ & $12(36.4)$ & & \\
\hline Attending $\mathrm{c}$ & & & & \\
\hline Yes & $73(86.9)$ & $11(13.1)$ & 0.016 & $0.43(0.21-0.85)$ \\
\hline No & $187(73.9)$ & $66(26.1)$ & & \\
\hline B10d. Chole & & & & \\
\hline $\begin{array}{l}\text { Attenaing c } \\
\text { Yes }\end{array}$ & $82(86.3)$ & $13(13.7)$ & 0.046 & $0.51(0.27-0.98)$ \\
\hline No & $229(76.6)$ & $70(23.4)$ & ט.0.0 & $0.51(0.21-0.00)$ \\
\hline Variable & Agree No. (\%) & Do not agree/uncertain No. (\%) & $P$ & HR \\
\hline C1. Raw foc & cooked foods & & & \\
\hline Education 1 & & & & \\
\hline 8 & $120(92.3)$ & $10(7.7)$ & 0.015 & $0.34(0.14-0.81)$ \\
\hline 13 & $183(81.0)$ & $43(19.0)$ & & \\
\hline 16 & $57(80.3)$ & $14(19.7)$ & & \\
\hline C2. Defrost & & & & \\
\hline Age & & & & \\
\hline$<35$ & $11(10.1)$ & $98(89.9)$ & 0.032 & $2.67(1.1-6.6)$ \\
\hline $35-50$ & $28(10.1)$ & $248(89.9)$ & 0.011 & $2.66(1.3-5.6)$ \\
\hline$>50$ & $12(23.1)$ & $40(76.9)$ & & \\
\hline Variable & Safe No. (\%) & Unsafe No. (\%) & $P$ & HR \\
\hline D4. Do you & unwrapped cooke & & & \\
\hline Length of $s$ & & & & \\
\hline$\leqslant 10$ & $110(66.7)$ & $55(33.3)$ & 0.006 & $3.12(1.38-7.05)$ \\
\hline $11-20$ & $142(74.7)$ & $48(25.3)$ & & \\
\hline$>20$ & $50(86.2)$ & $8(13.8)$ & & \\
\hline
\end{tabular}


Table 5 (continued)

\begin{tabular}{|c|c|c|c|c|}
\hline Variable & Safe No. (\%) & Unsafe No. (\%) & $P$ & HR \\
\hline \multicolumn{5}{|l|}{ Length of service/ward } \\
\hline$\leqslant 10$ & $111(67.3)$ & $54(32.7)$ & 0.018 & $2.85(1.20-6.77)$ \\
\hline $11-20$ & $133(73.1)$ & $49(26.9)$ & & \\
\hline$>20$ & $41(85.4)$ & $7(14.6)$ & & \\
\hline \multicolumn{5}{|l|}{ Education level } \\
\hline 8 & $82(64.1)$ & 46 (35.9) & & \\
\hline 13 & $180(81.1)$ & $42(18.9)$ & 0.019 & $0.48(0.27-0.88)$ \\
\hline 16 & $48(67.6)$ & $23(32.4)$ & & \\
\hline \multicolumn{5}{|l|}{ Answer to question B5 } \\
\hline Correct & $303(77.5)$ & $88(22.5)$ & $<0.0005$ & $0.29(0.18-0.47)$ \\
\hline Uncorrect/unknown & $46(50.0)$ & $46(50.0)$ & & \\
\hline \multicolumn{5}{|l|}{ Answer to question B6 } \\
\hline Correct & 264 (77.9) & $75(22.1)$ & $<0.0005$ & $0.40(0.26-0.61)$ \\
\hline Uncorrect/unknown & $75(58.1)$ & $54(41.9)$ & & \\
\hline
\end{tabular}

low. Furthermore, the study was conducted with all nursing homes and the only LTCF in the area surveyed with specialized inpatient services for individuals with mental illnesses. With a low response rate and a limited study population, these results may not reflect true food service practices in LTCFs and, therefore, may not be generalizable to other LTCFs. This survey is also limited by the fact that these data are self-reported. We could not observe or confirm the completion of surveys by respondents, who may have misinterpreted the statement and response choices.

Prevention is the more cost-effective strategy to avoid foodborne illnesses, but unsafe knowledge, attitudes and behaviours are widely diffuse among food workers, not only among consumers. Alternative educational strategies to the health belief model, based upon the theory that knowledge of perceived risks and benefits predict health behaviours, could be likely more effective. Food safety could be an ideal field where education and training could be organized in ways that integrate behavioural sciences with Public Health.

\section{Conclusion}

The need for more information regarding food hygiene through adequate education courses and continuous food safety training has been well evidenced by this study. Nevertheless, the majority of the food service staff in nursing home for the elderly and in the LTCF had attended at least one course on food hygiene and foodborne diseases. Therefore, the knowledge on food hygiene is insufficient to promote positive attitudes and safe behaviours. As reported in previous studies on hospital and LTCF catering (Angelillo, Foresta, et al., 2001; Angelillo, Viggiani, et al., 2001; Askarian et al., 2004; Buccheri et al., 2007; Endevelt, Werner, Goldman, \& Karpati, 2009; Nelson et al., 2008), there is the need for continuous training and for alternative educational strategies. In our study, although food safety knowledge were high, food-handling practices were not always consistent with accepted standards. Areas of improvement include training and education on appropriate food-handling practices and increased documentation of food safety practices, including end-point temperatures, and refrigerator and freezer temperatures.

Results of this study can form the basis of a program for implementing HACCP and indicate that employees in foodservice operations may have sufficient knowledge of food safety practices but need assistance with developing prerequisite programs in preparation for the HACCP program. Systems and training are needed to support proper food-handling practices in nursing homes and LTCFs, but probably too much reliance has been placed upon certificates and not enough on the personnel competence. The purpose of a internal surveillance is to identify specific hazards and then to establish a strategy of efficient control or successive elimination of hazards. It is also important to take care of human resource man- agement. A positive motivational atmosphere in working environment significantly contributes to higher productivity, and to general good feeling in workplace. Health-care professionals can play an important role in preventing foodborne illness by educating their patients about the risks of foodborne illness and reporting cases promptly to public health authorities. All food safety guidelines (washing hands frequently, cooking meat, poultry, fish and eggs properly, avoiding cross-contamination and keeping foods at safe temperatures) are fundamental in controlling foodborne illness in all populations, particularly for elderly and people at risk living in communities.

\section{References}

Altekruse, S. F., Yang, S., Timbo, B. B., \& Angulo, F. J. (1999). A multi-state survey of consumer food-handling and food-consumption practices. American Journal of Preventive Medicine, 16(3), 216-221.

Alvarez, J., Monereo, S., Ortiz, P., \& Salido, C. (2004). Management in clinical nutrition. Nutrición Hospitalaria, 19(3), 125-134.

Angelillo, I. F., Foresta, M. R., Scozzafava, C., \& Pavia, M. (2001). Consumers and foodborne diseases: Knowledge, attitudes, and reported behavior in one region of Italy. International Journal of Food Microbiology, 64(1-2), 161-166.

Angelillo, I. F., Viggiani, N. M., Greco, R. M., \& Rito, D. (2001). HACCP and food hygiene in hospitals: Knowledge, attitudes, and practices of food-services staff in Calabria, Italy. Collaborative Group. Infection Control and Hospital Epidemiology, 22, 363-369.

Angelillo, I. F., Viggiani, N. M., Rizzo, L., \& Bianco, A. (2000). Food handlers and foodborne diseases: Knowledge, attitudes, and reported behavior in Italy. Journal of Food Protection, 63(3), 381-385.

Askarian, M., Kabir, G., Aminbaig, M., Memish, Z. A., \& Jafari, P. (2004). Knowledge attitudes, and practices of food service staff regarding food hygiene in Shiraz, Iran. Infection Control and Hospital Epidemiology, 25(1), 16-20.

Buccheri, C., Casuccio, A., Giammanco, S., Giammanco, M., La Guardia, M., \& Mammina, C. (2007). Food safety in hospital: Knowledge, attitudes and practices of nursing staff of two hospitals in Sicily, Italy. BMC Health Services Research, 3(7), 45.

Cecchetto, G., Zanardo, M., \& Tossani, C. (2006). Polypathology, pharmacotherapy and malnutrition in the elderly: A study in hospitalized elderly. General Gerontology, 54(1), 11-16.

Decreto Legislativo No. 155 del 26.5.1997. Attuazione delle Direttive 93/43/CE concernenti l'igiene dei prodotti alimentari. Gazzetta Ufficiale della Repubblica Italiana, n.136 del 13.06.1997 Roma, Italy.

Dettenkofer, M., \& Spencer, R. C. (2007). Importance of environmental decontamination-a critical view. Journal of Hospital Infection, 65(June Suppl. 2), 55-57.

Endevelt, R., Werner, P., Goldman, D., \& Karpati, T. (2009). Nurses knowledge and attitudes regarding nutrition in the elderly. The Journal of Nutrition, Health and Aging, 13(6), 485-489.

Exner, M., Peters, G., Engelhart, S., Mielke, M., \& Nassauer, A. (2004). 1974-2004 The commission for hospital hygiene has been working for 30 years. From the "old" to the "new" guideline. Bundesgesundheitsblatt Gesundheitsforschung Gesundheitsschutz, 47(4), 313-322.

Geng, V., \& Thieves, M. (2002). Measures to promote hygiene in geriatric and longterm care. Gesundheitswesen, 64(10), 534-539.

Gerba, C. P., Rose, J. B., \& Haas, C. N. (1996). Sensitive populations: Who is at the greatest risk? International Journal of Food Microbiology, 30(1-2), 113-123.

Greig, J. D., \& Lee, M. B. (2009). Enteric outbreaks in long-term care facilities and recommendations for prevention: A review. Epidemiology and Infection, 137(2), 145-155.

Kendall, P. A., Hillers, V. V., \& Medeiros, L. C. (2006). Food safety guidance for older adults. Clinical Infectious Diseases, 42(9), 1298-1304. 
Klontz, K. C., Timbo, B., Fein, S., \& Levy, A. (1995). Prevalence of selected food consumption and preparation behaviors associated with increased risks of foodborne disease. Journal of Food Protection, 58(8), 927-930.

Layton, M. C., Calliste, S. G., Gomez, T. M., Patton, C., \& Brooks, S. (1997). A mixed foodborne outbreak with Salmonella heidelberg and Campylobacter jejuni in a nursing home. Infection Control and Hospital Epidemiology, 18(2), 115-121.

Levine, W. C., Smart, J. F., Archer, D. L., Bean, N. H., \& Tauxe, R. V. (1991). Foodborne disease outbreaks in nursing homes, 1975 through 1987. JAMA, 266(15), 2105-2109.

Martin, U., Behler, R., Bock-Hensley, O., Boschek, H. J., Fobbe, E., Gardemann, J., et al. (2001). Fundamentals of hygiene in old-age and nursing homes. Recommendations for nursing personnel and for hygiene control by German public health offices. Gesundheitswesen, 63(10), 640-642.

McGrath, C. (2003). Pfizer ageing population report on European Health Business Editors/Health/Medical Writers BRUSSELS, Belgium, (BUSINESS WIRE), June 24 2003.

Medeiros, L., Hillers, V., Kendall, P., \& Mason, A. (2001). Evaluation of food safety education for consumers. Journal of Nutrition Education, 33(Suppl. 1), S27-S34.

Nelson, J. M., Bednarczyk, R., Nadle, J., Clogher, P., Gillespie, J., Daniels, A., et al. (2008). FoodNet survey of food use and practices in long-term care facilities. Journal of Food Protection, 71(2), 365-372.

Nicolle, L. E. (2001). Preventing infections in non-hospital settings: Long-term care. Emerging Infectious Diseases, 7(2), 205-207.

Nicolle, L. E., Strausbaugh, L. J., \& Garibaldi, R. A. (1996). Infections and antibiotic resistance in nursing homes. Clinical Microbiology Reviews, 9(1), 1-17.
Parks, S. M., Haines, C., Foreman, D., McKinstry, E., \& Maxwel, M. S. N. (2005). Evaluation of an educational program for long-term care nursing assistants. Journal of the American Medical Directors Association, 6(1), 61-65.

Patil, S. R., Cates, S., \& Morales, R. (2005). Consumer food safety knowledge, practices, and demographic differences: Findings from a meta-analysis. Journal of Food Protection, 68, 1884-1894.

Regulation (EC) No. 852/2004 of the European Parliament and of the council on the hygiene of foodstuffs. Official journal No. L 226, 25.6.2004, pp. 3-21.

Salva, A., Coll-Planas, L., Bruce, S., De Groot, L., Andrieu, S., Abellan, G., et al. (2009). Nutritional assessment of residents in long-term care facilities (LTCFs): Recommendations of the task force on nutrition and ageing of the IAGG european region and the IANA. The Journal of Nutrition, Health and Aging, 13(6), 475-483.

Smith, J. L. (1998). Foodborne illness in the elderly. Journal of Food Protection, 61(9), 1229-1239.

Strausbaugh, L. J. (2001). Emerging health care-associated infections in the geriatric population. Emerging Infectious Diseases, 7(2), 268-271.

Tokuç, B., Ekuklu, G., Berberoğlu, U., Bilge, E., \& Dedeler, H. (2009). Knowledge, attitudes and self-reported practices of food service staff regarding food hygiene in Edirne, Turkey. Food Control, 20(6), 565-568.

Zimmerman, S., Gruber-Baldini, A. L., Hebel, J. R., Sloane, P. D., \& Magaziner, J. (2002). Nursing home facility risk factors for infection and hospitalization: Importance of registered nurse turnover, administration, and social factors. Journal of the American Geriatrics Society, 50(12), 1987-1995. 